\title{
EVALUASI ASET FASILITAS PADA WANAWISATA PUNCELING DI KABUPATEN BANDUNG
}

\author{
Rizka Annisa ${ }^{1}$ \\ Tiafahmi Angestiwi ${ }^{2}$ \\ Program Studi Manajemen Aset Politeknik Negeri Bandung ${ }^{1,2}$ \\ Penulis Koresponden e-mail: rizka.annisa.mas16@polban.ac.id
}

\begin{abstract}
Punceling Forest Tourism have an appeal that consisting of a hill keraton, the Pancuran Tujuh , Lumpat Waterfall , Pajajaran Waterfall, and Kebul waterfall. But, there is an indication matter found in wanawisata punceling namely the difficulty of tourists to find the entrance. This case study devoted to know the quality of assets facilities wanawisata punceling based on dimensions accommodation, access, attractiveness , and supporting facilities. The research was done by using the method descriptive with a qualitative approach and qualitative. Technique data collection was carried out by observation, interview, the questionnaire and documentation. The results showed that the quality based on the dimensions of the supporting facilities showed poor quality. This is indicated by $71 \%$ of the condition of the facility that does not meet the criteria while $29 \%$ of the condition of the facility has met the criteria with the existing conditions

Keywords: Assets facilities, Forest Tourism, Nature Tourism
\end{abstract}

Wanawisata Punceling memiliki daya tarik yang terdiri dari Bukit Keraton, Pancuran Tujuh, Curug Lumpat, Curug Pajajaran, dan Curug Kebul. Namun, terdapat indikasi masalah yang ditemukan di Wanawisata Punceling yakni sulitnya wisatawan untuk menemukan pintu masuk. Studi kasus ini ditujukan untuk mengetahui kualitas aset fasilitas Wanawisata Punceling berdasarkan dimensi akomodasi, akses, daya tarik, dan fasilitas pendukung. Penelitian dilakukan dengan menggunakan metode deskriptif dengan pendekatan kualitatif dan kuantitatif. Teknik pengumpulan data dilakukan dengan observasi, wawancara, kuesioner dan dokumentasi. Hasil penelitian menunjukkan kualitas berdasarkan dimensi fasilitas pendukung menunjukkan kualitas yang kurang baik. Hal ini ditandai dengan 71\% keadaan fasilitas yang tidak memenuhi kriteria sedangkan $29 \%$ keadaan fasilitas telah memenuhi kriteria dengan kondisi eksisting Kata kunci: Aset Fasilitas, Wanawisata, Wisata Alam 


\section{PENDAHULUAN}

Wanawisata Punceling adalah objek wisata yang dimiliki Kesatuan Pemangkuan Hutan (KPH) Bandung Selatan Divisi Regional Jawa Barat dan Banten yang beralamat di Desa Alam Endah, Kecamatan Rancabali, Kabupaten Bandung. Luas objek wisata tersebut yakni 72,9 Ha. Berikut adalah peta kawasan Wanawisata Punceling (Gambar 1). Daya tarik yang ditawarkan Wanawisata Punceling diantaranya yakni Bukit Keraton, Pancuran Tujuh, Curug Lumpat, Curug Pajajaran, dan Curug Kebul. Namun, beragamnya daya tarik tidak luput dari beberapa masalah yang ada pada Wanawisata Punceling.

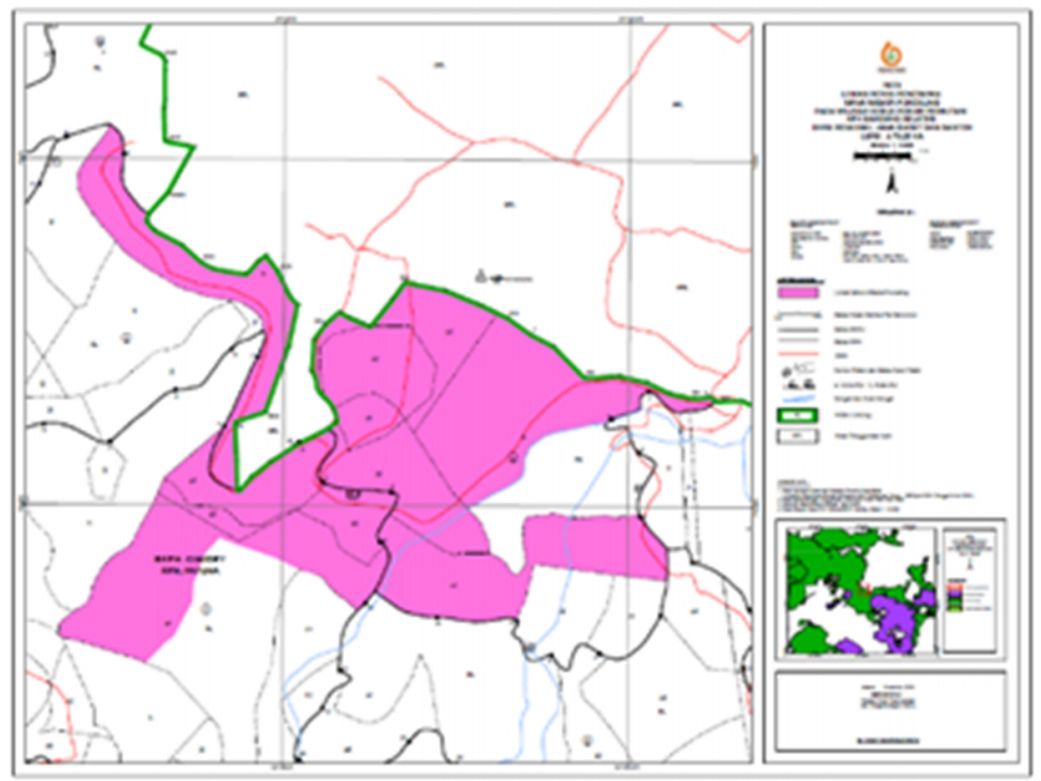

Gambar 1. Peta Kawasan Wanawisata Punceling Sumber: Perum Perhutani KPH Bandung Selatan, 2019

Tempat berkemah (camping ground) menjadi salah satu tujuan wisatawan untuk berkunjung ke Wanawisata Punceling. Tercatat terdapat 1.497 pengunjung yang datang hanya untuk berkemah pada Wanawisata Punceling pada bulan November. Antusiasme pengunjung sangat tinggi untuk berkemah. Namun, karena tidak adanya tata letak untuk yang jelas untuk mendirikan tenda maka pengunjung mendirikan tenda dimana saja (Gambar 2). 


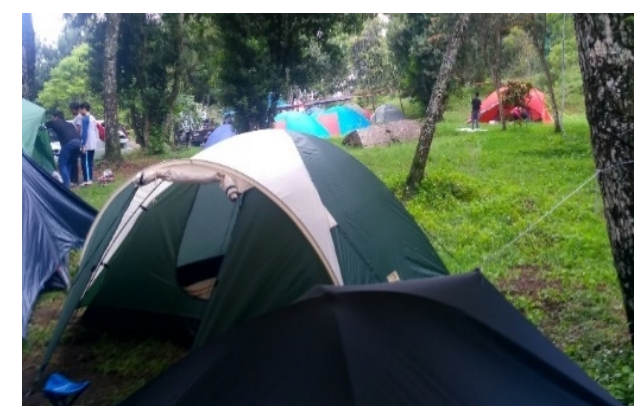

Gambar 2. Area Perkemahan Wanawisata Punceling Sumber: Penyusun, 2019

Wanawisata Punceling memiliki satu jalan untuk menuju obyek wisata tersebut. Biasanya, pengunjung menggunakan kendaraan pribadi untuk menuju Wanawisata Punceling. Pengunjung harus berhati-hati untuk mengakses jalan yang menuju wisata tersebut. Hal tersebut dikarenakan jalan yang rusak karena tergenang air yang dapat dilihat pada Gambar 3 .

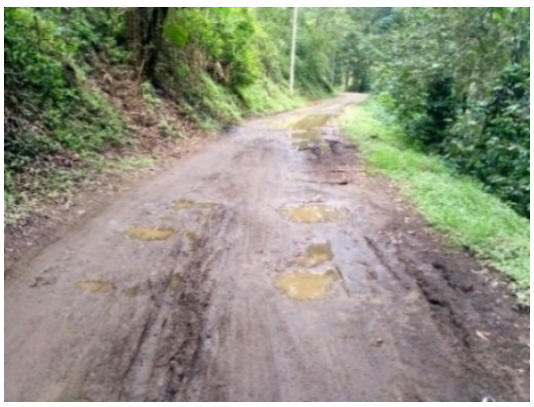

Gambar 3. Akses Jalan Menuju Wanawisata Punceling Sumber: Penyusun, 2019

Wanawisata Punceling memiliki fasilitas kolam rendam dan kolam pemandian air panas. Hal tersebut menjadi tujuan rekreasi yang dimiliki oleh obyek wisata alam tersebut. Akan tetapi, tidak semua pengunjung tertarik menggunakan fasilitas tersebut. Hal ini dikarenakan kondisi fasilitas yang terlihat tidak terawat dengan ditandai adanya noda kecoklatan pada dinging-dinding fasilitas tersebut (Gambar 4). 


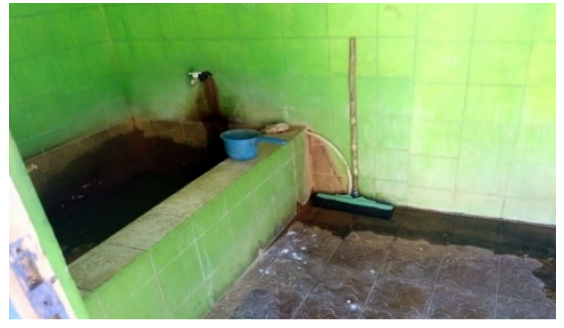

a) Kolam Rendam

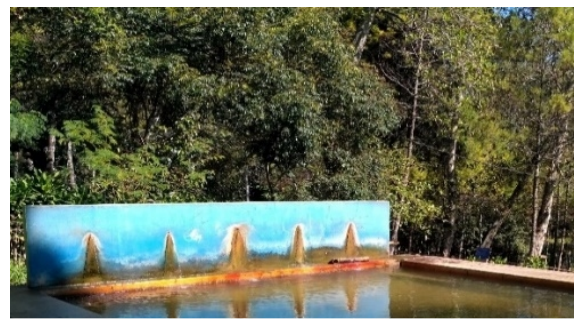

b) Kolam Pemandian Air Panas

Gambar 4. Fasilitas Rekreasi pada Wanawisata Punceling Sumber: Penyusun, 2019

Wanawisata Punceling memiliki satu pintu masuk yang terletak di pinggir Jalan Ciwidey-Patengan. Meskipun pintu masuk terletak di pinggir jalan, wisatawan kesulitan untuk menemukan pintu masuk sehingga obyek wisata alam tersebut sering terlewati. Hal tersebut disebabkan karena belum tersedianya papan nama pada wanawisata ini. Kondisi pintu masuk menuju Wanawisata Punceling dapat dilihat pada Gambar 5.

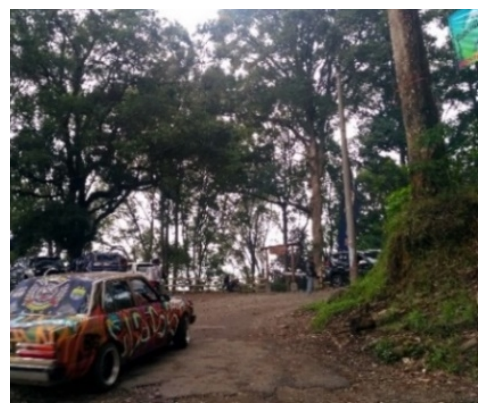

Gambar 5. Kondisi Pintu Masuk Menuju Wanawisata Punceling Sumber: Penyusun, 2019

Berdasarkan penjelasan diatas, maka perlu dilakukan evaluasi mengenai aset fasilitas Wanawisata Punceling. Hal tersebut diharapkan dapat menjadi acuan untuk meningkatkan kualitas fasilitas yang pada objek wisata tersebut. Oleh karena itu, Peneliti tertarik untuk melakukan penelitian studi kasus yang berjudul "Evaluasi Aset Fasilitas pada Wanawisata Punceling di Kabupaten Bandung".

\section{METODOLOGI}

Metode yang digunakan dalam penelitian ini yakni studi deskriptif. Menurut Sekaran (2006), metode deskriptif adalah studi yang dilakukan untuk mengetahui dan menjadi mampu 
untuk menjelaskan karakteristik variabel yang diteliti dalam suatu keadaan. Hal tersebut bertujuan untuk memberikan kepada peneliti sebuah gambaran aspek-aspek yang relevan dengan fenomena perhatian dari perspektif seseorang, organisasi, dan orientasi industri. Pada penelitian ini, teknik pengumpulan data yang digunakan yakni teknik wawancara, observasi, kuesioner, dan dokumentasi.

Penelitian ini menggunakan pendekatan kuantitatif. Menurut Sugiyono (2017), pendekatan kuantitatif menekankan pada angka-angka (perhitungan) dan analisis menggunakan statistik. Penelitian aset Kawasan Wanawisata Punceling Kabupaten Bandung. Pendekatan kuantitatif digunakan untuk mengetahui kualitas aset fasilitas berdasarkan kriteria dimensi akomodasi (accomodation), aksesibilitas (access), daya tarik (attraction) dan fasilitas pendukung (supporting facilities) (Priskin 2001; Panasiuk 2007; Alkahtani et. al (2015); Alaeddinoglu \& Can (2011); Ginting \& Sasmita 2018). yang ada di Wanawisata Punceling Kabupaten Bandung berdasarkan hasil kuesioner. Adapun instrumen yang digunakan dalam kuesioner dapat dilihat pada Tabel 1.

Tabel 1. Instrumen Kuesioner

\begin{tabular}{|c|l|c|}
\hline No. & \multicolumn{1}{|c|}{ Pertanyaan/Pernyataan Penelitian } & Kode Pertanyaan \\
\hline 1. & $\begin{array}{l}\mid \\
\text { Apakah area perkemahan yang ada telah mencukupi kebutuhan } \\
\text { akomodasi wisatawan? }\end{array}$ & A2 \\
\hline 2. & Area perkemahan yang ada telah tertata dengan baik. & A3 \\
\hline 3. & Fasilitas toilet bersih. & FP6 \\
\hline 4. & Ketersediaan air bersih mencukupi. & FP7 \\
\hline 5. & Jalur yang ada dapat dilewati dengan mudah oleh pejalan kaki. & FP15 \\
\hline 6. & Jumlah kursi yang tersedia telah mencukupi kebutuhan wisatawan & FP16 \\
\hline 7. & Meja piknik yang tersedia telah mencukupi kebutuhan wisatawan. & FP18 \\
\hline 8. & Outlet makanan yang tersedia tertata dengan rapi. & FP22 \\
\hline 9. & Karpet pada mushola atau masjid tidak berbau. & FP35 \\
\hline 10. & Jumlah tempat sampah telah mencukupi. & FP39 \\
\hline 11. & Fasilitas rekreasi dalam kondisi terawat. & DT1 \\
\hline
\end{tabular}

Menurut Kerlinger (1986), skala Likert adalah skala peringkat yang teringkas di mana skor individual pada skala adalah jumlah, atau rata-rata, dari respons individu terhadap beberapa item pada instrumen. Warmbrod (2014) menyatakan bahwa rangkaian respons untuk setiap pernyataan adalah skala linier yang menunjukkan sejauh mana responden setuju atau tidak setuju dengan setiap pernyataan. Misalnya, rangkaian respons generik untuk mendukung pertanyaan konstruk dapat dilihat pada Tabel 2. 
Tabel 2. Interval Interspretasi Skala Likert

\begin{tabular}{|c|l|}
\hline Skala & \multicolumn{1}{|c|}{ Interpretasi } \\
\hline $1-1,99$ & Sangat Tidak Setuju \\
\hline $2-2,99$ & Tidak Setuju \\
\hline $3-3,99$ & Cukup \\
\hline $4-4,99$ & Setuju \\
\hline 5 & Sangat Setuju \\
\hline
\end{tabular}

Sumber: Penyusun, 2019

Evaluasi adalah keputusan mengenai signifikansi, nilai, atau kualitas sesuatu, berdasarkan penelitian yang cermat terhadap karakteristir-karakteristik yang baik dan buruk (Calidoni dan Lundberg, 2006). Moha dan Loindong (2016) berpendapat bahwa fasilitas dapat berupa segala sesuatu yang memudahkan konsumen dalam mendapat kepuasan. Menurut Utama (2017), wisata alam atau cagar alam adalah perjalanan menuju tempat atau wilayah cagar alam, taman lindung, dan hutan daerah pegunungan yang dilindungi oleh undangundang kelestariannya. Maka dapat disimpulkan bahwa evaluasi aset fasilitas wisata alam adalah suatu keputusan terhadap baik atau buruknya kualitas fasilitas yang dapat memudahkan konsumen pada wisata alam untuk mendapatkan kepuasan yang didasari oleh penelitian yang cermat.

Ginting dan Sasmita (2018) berpendapat bahwa untuk mendukung pencapaian pembangunan, perlu dilakukan mengembangkan produk yang memiliki hubungan di bidang pariwisata yakni adalah pengembangan fasilitas pariwisata. Pembangunan pariwisata, berorientasi terhadap kebutuhan lingkungan, ekonomi dan sosial budaya (Rahman, 2019). Hal tersebut dapat dijadikan sebagai evaluasi atas fasilitas wisata yang ada pada suatu objek wisata dimana hal tersebut dapat menjadi dasar untuk mengembangkan pariwisata pada objek wisata tersebut. Menurut Ginting dan Sasmita (2018) terdapat tiga dimensi pada fasilitas wisata yakni akomodasi (accomodation), fasilitas pendukung (supporting facilities), dan fasilitas pendukung pariwisata (tourism auxiliary facilities). Selain itu, menurut Priskin (2001), untuk menilai fasilitas suatu wisata alam maka dapat dievaluasi berdasarkan empat komponen yakni daya tarik (attractions), akses (access), infrastruktur pendukung (supporting infrastructure) dan tingkat degradasi lingkungan (level of environmental degradation). Pada penelitian ini, dimensi yang digunakan untuk mengevaluasi aset fasilitas wisata alam yakni akomodasi (accomodation), akses (access), daya tarik (attractions), dan fasilitas pendukung (supporting facilities). 


\section{Akomodasi (Accommodation)}

Menurut Ginting dan Sasmita (2018), akomodasi adalah segala yang disediakan untuk memenuhi kebutuhan seseorang di mana wisatawan dapat beristirahat, menginap, mandi, makan dan minum, dan menikmati layanan - layanan wisata seperti fasilitas hiburan yang disediakan. Berikut adalah indikator dari dimensi akomodasi yaitu penginapan dan berkemah (Ginting \& Sasmita, 2018; Panasiuk, 2007).

2. Akses (Access)

Menurut Priskin (2001), aksesibilitas berkaitan dengan kemudahan yang tujuan dapat dicapai secara fisik, serta kemudahan tujuan itu sendiri dapat dinikmati sebagai produk pariwisata. Evaluasi berdasarkan dimensi akses dapat ditentukan berdasarkan indikator tipe jalan yang dapat diakses ke tempat wisata dan kendaraan yang dapat mengakses ke tempat wisata berikut (Priskin, 2001).

\section{Fasilitas Pendukung (Supporting Facilities)}

Priskin (2001) berpendapat bahwa kurangnya fasilitas di tempat-tempat wisata dapat menghalangi orang mengunjungi tempat atau menghambat kunjungan kembali. Hal tersebut menunjukkan bahwa ketersediaan fasilitas pendukung adalah hal yang sangat penting bagi suatu wisata (Priskin, 2001). Sedangkan, Ginting dan Sasmita (2018) berpendapat bahwa fasilitas pendukung seperti fasilitas yang proporsional sebagai pelengkap fasilitas utama sehingga wisatawan akan merasa lebih nyaman. Indikator yang digunakan pada penelitan ini yaitu terdiri dari 18 indikator yaitu area parkir, akses untuk disabilitas, barbeque/ fasilitas memanggang, fasilitas toilet, fasilitas air minum, fasilitas kebersihan dan keamanan, jalur, kursi / bangku, meja piknik, outlet makanan, penunjuk arah, pertolongan pertama, pintu gerbang, pusat informasi, tempat bernaung/berteduh, tempat ibadah, tempat sampah, dan toko suvenir (Priskin, 2001; Alaeddinoglu dan Can, 2011; Alkahtani et. al, 2015; Ginting \& Sasmita, 2018).

\section{Daya Tarik (Attractions)}

Daya tarik adalah alasan utama untuk melakukan perjalanan ketujuan tertentu (Roday et. al, 2009). Priskin (2001) berpendapat bahwa kekurangan fasilitas di tempat wisata dapat menghalangi orang mengunjungi tempat atau mencegah pengunjung untuk datang kembali. 
yang dapat dilihat pada Pada penelitian ini, indikator yang digunakan untuk mengevaluasi aset fasilitas yang ada di Wanawisata Punceling berdasarkan dimensi daya hanya menggunakan dua indikator yaitu fasilitas rekreasi dan fasilitas petualangan (Alaeddinoglu \& Can, 2011).

Penelitian ini menggunakan beberapa landasan normatif yang berlaku. Landasan normatif digunakan sebagai acuan standar fasilitas yang semestinya tersedia pada suatu obyek wisata. Landasan normatif yang digunakan pada penelitian ini adalah sebagai berikut:

a. Peraturan Menteri Kehutanan Republik Indonesia Nomor P.22/Menhut-11/2012 tentang Pedoman Kegiatan Usaha Pemanfaatan Jasa Lingkungan Wisata Alam Pada Hutan Lindung

b. Peraturan Pemerintah Republik Indonesia No. 50 Tahun 2011 Kepariwisataan Nasional tahun 2010-2025

c. Peraturan Menteri Pariwisata dan Ekonomi Kreatif Republik Indonesia Nomor 17 Tahun 2014

\section{HASIL DAN PEMBAHASAN}

Pada subbab ini akan dijelaskan mengenai hasil atas pengumpulan data dan analisis data. Subbab ini bertujuan untuk menjelaskan masalah terkait dengan kualitas aset fasilitas Wanawisata Punceling. Berdasarkan hasil penelitian melalui kuesioner, observasi, wawancara, dan dokumentasi dapat diketahui kualitas aset fasilitas Wanawisata Punceling yang ditinjau dari dimensi akomodasi, akses, daya tarik, dan fasilitas pendukung.

Menurtut Suhartanto (2014), pengukuran variabel yang khususnya berupa konstruk sangat komplek karena sebuah konstruk (variabel) perlu diukur dengan beberapa item/indikator sehingga dapat dimungkinkan apabila pengukuran yang dilakukan periset tidak tepat/akurat walaupun variabel telah ditentukan dan diukur dengan hati-hati. Oleh karena itu, maka perlu dilakukan uji validitas dan reabilitas.

Menurut Suhartanto (2014), validitas dapat menguji dari baiknya sebuah instrumen yang dibangun untuk mengukur suatu rancangan adalah betul-betul dapan mengukur rancangan tersebut. Sedangkan, reliabilitas menandakan konsistensi sebuah instrumen dalam mengukur suatu rancangan dan membantu untuk memasuki "the goodness" suatu pengukuran data (Suhartanto, 2014). Kuesioner yang diolah sebagai instrumen penelitian evaluasi aset fasilitas Wanawisata Punceling ini berdasarkan jawaban dari 50 responden. Berikut adalah 
hasil olah data berupa uji reabilitas dan validitas dari kuesioner yang dapat dilihat pada Tabel 3.

Tabel 3. Uji Reabilitas

\begin{tabular}{|c|c|c|}
\hline Cronbach's Alpha & Cronbach's Alpha Based on Standardized Items & N of Items \\
\hline 0,778 & 0,793 & 11 \\
\hline
\end{tabular}

Sumber: Analisis Penyusun, 2019

Menurut Wiyono (2011), secara umum the rule of thumb dari reliability adalah 0.7 artinya skor alpha 0.7 atau lebih dianggap sebagai reliabel. Berdasarkan uji reliabilitas, Cronbach's Alpha yang ditunjukan pada hasil uji ini sebesar 0.778. maka, dapat disimpulkam bahwa instrumen kuisioner yang digunakan untuk mengukur kualitas fasilitas aset yang ada di Wanawisata Punceling reliable.

Adapun hasil uji validitas pada instrumen kuesioner evaluasi aset fasilitas pada Wanawisata Punceling dapat dilihat pada Tabel 4.

Tabel 4. Uji Validitas

\begin{tabular}{|c|c|c|c|c|}
\hline No. & Kode Pertanyaan & Signifikansi (5\%) & Pearson Correlation & Keterangan \\
\hline 1. & A2 & 0,000 & 0,524 & Valid \\
\hline 2. & A3 & 0,000 & 0,576 & Valid \\
\hline 3. & FP6 & 0,000 & 0,632 & Valid \\
\hline 4. & FP7 & 0,000 & 0,475 & Valid \\
\hline 5. & FP15 & 0,000 & 0,555 & Valid \\
\hline 6. & FP16 & 0,000 & 0,596 & Valid \\
\hline 7. & FP18 & 0,000 & 0,559 & Valid \\
\hline 8. & FP22 & 0,003 & 0,416 & Valid \\
\hline 9. & FP35 & 0,000 & 0,690 & Valid \\
\hline 10. & FP39 & 0,000 & 0,679 & Valid \\
\hline 11. & DT1 & 0,000 & 0,544 & Valid \\
\hline
\end{tabular}

Sumber: Analisis Penyusun, 2019

Hair et. al (1998) mengemukakan bahwa uji validitas dilakukan dengan cara melihat apakah setiap butir pertanyaan memiliki nilai korelasi lebih besar dari 0,4. Berdasarkan uji validitas, semua instrumen menunjukkan hasil koefisien berada di atas nilai 0,4. Maka, dapat disimpulkan bahwa instrumen yang digunakan untuk mengevaluasi aset fasilitas pada Wanawisata Punceling valid. Hasil olah data kuesioner dapat mendukung hasil observasi dan wawancara. Berikut adalah pembahasan mengenai evaluasi aset fasilitas Wanawisata Punceling yang ditinjau dari dimensi akomodasi, akses, daya tarik, dan fasilitas pendukung. 


\subsection{Hasil Evaluasi Dimensi Akomodasi}

Menurut Aminuddin et. al (2016), akomodasi adalah sesuatu yang disediakan untuk memenuhi kebutuhan, misalnya tempat menginap atau tempat tinggal sementara bagi orang yang bepergian. Ginting \& Sasmita (2018) menjelaskan bahwa fasilitas akomodasi terdiri dari hotel atau penginapan (hotel / lodging), tempat makan (eating places), dan fasilitas hiburan (entertainment facilities). Disisi lain, menurut Panasiuk (2007) hotel (hotels), penginapan (lodges), apartemen (apartments), hostel (hostels), dan berkemah (campings). Namun, pada evaluasi fasilitas akomodasi pada Wanawisata Punceling menggunakan dua indikator yaitu penginapan dan berkemah. Hal tersebut mengacu kepada Peraturan Menteri Kehutanan Republik Indonesia Nomor : P.22/Menhut-Ii/2012 Tentang Pedoman Kegiatan Usaha Pemanfaatan Jasa Lingkungan Wisata Alam Pada Hutan Lindung bahwa pembangunan sarana akomodasi yang dimungkinkan terdapat pada wisata alam hanya kedua indikator tersebut.

Tabel 5. Hasil Kuesioner Indikator Berkemah

\begin{tabular}{|l|c|c|c|c|c|c|}
\hline \multicolumn{1}{|c|}{ Pertanyaan } & Kode & N & $\begin{array}{c}\text { Mini } \\
\text { mum }\end{array}$ & Maximum & Mean & Interpretasi \\
\hline $\begin{array}{l}\text { Apakah area perkemahan } \\
\text { yang ada telah mencukupi } \\
\text { kebutuhan akomodasi } \\
\text { wisatawan? }\end{array}$ & A2 & 50 & 2 & 5 & 3,04 & Cukup \\
\hline $\begin{array}{l}\text { Area perkemahan yang } \\
\text { ada telah tertata dengan } \\
\text { baik. }\end{array}$ & A3 & 50 & 2 & 5 & 3,32 & Cukup \\
\hline
\end{tabular}

Sumber: Analisis Penyusun, 2019

Berdasarkan hasil kuesioner Tabel 5, persepsi pengunjung menunjukkan bahwa ketersediaan area perkemahan, namun hal tersebut berbeda dengan hasil wawancara yang menunjukkan bahwa kapasitas sudah tidak mencukupi. Adapun tata letak menunjukkan hasil cukup Adapun hasil evaluasi dari dimensi akomodasi pada obyek wisata alam ini adalah sebagai berikut yang dapat dilihat pada Tabel 6 .

Tabel 6. Hasil Evaluasi Dimesi Akomodasi

\begin{tabular}{|c|c|l|l|}
\hline No. & Indikator & \multicolumn{1}{|c|}{ Kriteria } & \multicolumn{1}{|c|}{ Hasil } \\
\hline 1. & Penginapan & $\begin{array}{l}\text { Tersedia penginapan pada Wanawisata } \\
\text { Punceling }\end{array}$ & Tidak tersedia. \\
\hline 2. & Berkemah & $\begin{array}{l}\text { Area perkemahan telah mencukupi } \\
\text { kebutuhan akomodasi wisatawan. }\end{array}$ & $\begin{array}{l}\text { Permintaan pengunjung melebihi } \\
\text { kapasitas perkemahan yang telah } \\
\text { disediakan. }\end{array}$ \\
\cline { 3 - 4 } & & Area perkemahan telah tertata dengan rapi. & Cukup tertata dengan baik \\
\hline
\end{tabular}

Sumber: Analisis Penyusun, 2019 


\subsection{Hasil Evaluasi Dimensi Akses}

Menurut Priskin (2001), akses berkaitan dengan kemudahan yang tujuan dapat dicapai secara fisik, serta kemudahan tujuan itu sendiri dapat dinikmati sebagai produk pariwisata. Evaluasi aksesibilitas wisata alam terdiri dari dua indikator yaitu tipe jalan yang dapat diakses ke tempat wisata dan kendaraan yang dapat mengakses ke tempat wisata di Wanawisata Punceling. Adapun hasil observasi dari evaluasi dimensi akses pada obyek wisata alam ini adalah sebagai berikut yang dapat dilihat pada Tabel 7 .

Tabel 7. Hasil Evaluasi Dimesi Akses

\begin{tabular}{|c|c|c|c|}
\hline No. & Indikator & Kriteria & Hasil \\
\hline 1. & $\begin{array}{l}\text { Tipe Jalan yang dapat } \\
\text { Diakses ke Tempat } \\
\text { Wisata }\end{array}$ & Tidak berkerikil. & $\begin{array}{l}\text { Berkerikil dan tergenang } \\
\text { air. }\end{array}$ \\
\hline \multirow[t]{2}{*}{2.} & \multirow{2}{*}{$\begin{array}{llr}\text { Kendaraan yang dapat } \\
\text { Mengakses ke Tempat } \\
\text { Wisata }\end{array}$} & $\begin{array}{l}\text { Dapat dilalui semua jenis } \\
\text { kendaraan bermotor. }\end{array}$ & $\begin{array}{l}\text { Dapat dilalui semua jenis } \\
\text { kendaraan bermotor. }\end{array}$ \\
\hline & & $\begin{array}{l}\text { Tersedia pelayanan } \\
\text { angkutan umum. }\end{array}$ & $\begin{array}{l}\text { Tersedia pelayanan } \\
\text { angkutan perkotaan. }\end{array}$ \\
\hline
\end{tabular}

Sumber: Analisis Penyusun, 2019

Berdasarkan Tabel 7, diketahui bahwa kondisi jalan pada Wanawisata Punceling kurang baik meskipun masih dapat dilalui kendaraan bermotor dan pelayanan angkutan umum tersedia.

\subsection{Hasil Evaluasi Dimensi Daya Tarik}

Daya tarik adalah alasan utama untuk melakukan perjalanan ketujuan tertentu (Roday et. al, 2009). Evaluasi daya tarik wisata alam terdiri dari dua indikator yaitu fasilitas rekreasi dan petualangan (Alaeddinoglu dan Can, 2011). Hasil observasi fasilitas rekreasi menunjukkan bahwa terdapat dinding kecoklatan pada kolam pemandian air panas dan kamar rendam. Kurang baiknya fasilitas tersebut pun didukung oleh hasil kuesioner pada Tabel 8.

Tabel 8. Hasil Kuesioner Indikator Fasilitas Rekreasi

\begin{tabular}{|l|c|c|c|c|c|c|}
\hline \multicolumn{7}{|c|}{ Descriptive Statistics } \\
\hline \multicolumn{1}{|c|}{ Pertanyaan } & Kode & N & Minimum & Maximum & Mean & Interpretasi \\
\hline $\begin{array}{l}\text { Fasilitas rekreasi dalam } \\
\text { kondisi terawat. }\end{array}$ & DT1 & 50 & 1 & 5 & 2,70 & Tidak Setuju \\
\hline
\end{tabular}

Sumber: Analisis Penyusun, 2019

Berdasarkan Tabel 8, pengunjung menyatakan tidak setuju jika fasilitas rekreasi yang ada di Wanawisata Punceling dikatakan telah baik. Berdasarkan hasil observasi dan kuesioner 
tersebut diketahui bahwa fasilitas rekreasi yang ada kurang baik. Pada indikator fasilitas petualangan, hasil observasi menunjukan hal berikut.

Tabel 9. Hasil Observasi Indikator Fasilitas Petualangan

\begin{tabular}{|c|c|c|c|}
\hline No. & Fasilitas & Kriteria & Hasil \\
\hline 1 & Outbond & $\begin{array}{l}\text { Ketersediaan. fasilitas } \\
\text { outbond. }\end{array}$ & Tidak tersedia \\
\hline 2 & Flying fox & $\begin{array}{l}\text { Ketersediaan fasilitas } \\
\text { kabel luncur (flying } \\
\text { fox). }\end{array}$ & Tidak tersedia \\
\hline 3 & Canopy trail & $\begin{array}{l}\text { Ketersediaan fasilitas } \\
\text { jembatan antar tajuk } \\
\text { pohon (canopy trail). }\end{array}$ & Tidak tersedia \\
\hline 4 & Balon udara & $\begin{array}{l}\text { Ketersediaan fasilitas } \\
\text { balon udara. }\end{array}$ & $\begin{array}{l}\text { Tidak tersedia (dilihat dari } \\
\text { kondisi pohon-pohon pinus } \\
\text { tinggi pada Wanawisata } \\
\text { Punceling menyebabkan } \\
\text { fasilitas paralayang tidak } \\
\text { dapat memungkinkan untuk } \\
\text { tersedia). }\end{array}$ \\
\hline 5 & Paralayang & $\begin{array}{l}\text { Ketersediaan fasilitas } \\
\text { paralayang. }\end{array}$ & $\begin{array}{l}\text { Tidak tersedia (dilihat dari } \\
\text { kondisi pohon-pohon pinus } \\
\text { tinggi pada Wanawisata } \\
\text { Punceling menyebabkan } \\
\text { fasilitas paralayang tidak } \\
\text { dapat memungkinkan untuk } \\
\text { tersedia). }\end{array}$ \\
\hline 6 & Jungle track & $\begin{array}{l}\text { Ketersediaan fasilitas } \\
\text { jalan hutan (jungle } \\
\text { track) }\end{array}$ & Tersedia. \\
\hline
\end{tabular}

Sumber: Analisis Penyusun, 2019

Berdasarkan Tabel 9, diketahui bahwa Wanawisata Punceling belum memiliki fasilitas outbond, flying fox, canopy trail, balon udara, paralayang pada fasilitas petualangannya. Oleh karena itu fasilitas petualangan yang ada di wanawisata tersebut kurang baik.

Dilihat dari hasil observasi dan kuesioner, fasilitas rekreasi dinilai tidak terawat dan fasilitas petualangan belum lengkap. Maka dapat disimpulkan bahwa kualitas dimensi daya tarik pada Wanawisata Punceling kurang baik.

\subsection{Hasil Evaluasi Dimensi Fasilitas Pendukung}

Ginting dan Sasmita (2018) berpendapat bahwa fasilitas pendukung seperti fasilitas yang proporsional sebagai pelengkap fasilitas utama sehingga wisatawan akan merasa lebih nyaman. Evaluasi fasilitas pendukung wisata alam terdiri dari 18 indikator yaitu area parkir, 
akses untuk disabilitas, barbeku, fasilitas toilet, fasilitas air minum , fasilitas kebersihan dan keamanan, jalur, kursi/bangku, meja piknik, outlet makanan, petunjuk, pertolongan pertama, pintu gerbang, pusat informasi, tempat bernaung/berteduh, empat ibadah, tempat sampah, dan toko suvenir. Adapun hasil kuesioner berdasarkan persepsi pengunjung mengenai fasilitas yang tersedia dapat dilihat pada Tabel 10.

Tabel 10. Hasil Kuesioner Fasilitas Pendukung

\begin{tabular}{|c|c|c|c|c|c|c|}
\hline \multicolumn{7}{|c|}{ Descriptive Statistics } \\
\hline Pertanyaan & Kode & $\mathbf{N}$ & Minimum & Maximum & Mean & Interpretasi \\
\hline Fasilitas toilet bersih. & FP6 & 50 & 1 & 5 & 2,74 & Tidak Setuju \\
\hline Ketersediaan air bersih mencukupi. & FP7 & 50 & 1 & 5 & 3,58 & Setuju \\
\hline $\begin{array}{l}\text { Jalur yang ada dapat dilewati dengan } \\
\text { mudah oleh pejalan kaki. }\end{array}$ & FP16 & 50 & 1 & 4 & 2,16 & Tidak Setuju \\
\hline $\begin{array}{l}\text { Jumlah kursi yang tersedia telah } \\
\text { mencukupi kebutuhan wisatawan. }\end{array}$ & FP15 & 50 & 1 & 5 & 3,14 & Cukup \\
\hline $\begin{array}{l}\text { Meja piknik yang tersedia telah } \\
\text { mencukupi kebutuhan wisatawan. }\end{array}$ & FP18 & 50 & 1 & 5 & 1,84 & $\begin{array}{l}\text { Sangat Tidak } \\
\text { Setuju }\end{array}$ \\
\hline $\begin{array}{l}\text { Outlet makanan yang tersedia tertata } \\
\text { dengan rapi. }\end{array}$ & FP22 & 50 & 1 & 5 & 2,72 & Tidak Setuju \\
\hline $\begin{array}{l}\text { Karpet pada mushola atau masjid } \\
\text { tidak berbau. }\end{array}$ & FP35 & 50 & 1 & 5 & 2,70 & Tidak Setuju \\
\hline $\begin{array}{l}\text { Jumlah tempat sampah telah } \\
\text { mencukupi. }\end{array}$ & FP39 & 50 & 1 & 4 & 2,28 & Tidak Setuju \\
\hline
\end{tabular}

Sumber: Analisis Penyusun, 2019

Berdasarkan hasil kuesioner pada Tabel 10 menunjukkan bahwa pengunjung tidak setuju jika kebersihan toilet, akses jalur, tertatanya outlet makanan, kualitas karpet mushola, dan jumlah tempat sampah telah baik. Sedangkan ketersediaan jumlah kursi dinilai cukup dan ketersediaan air bersih dinilai memadai. Hal ini pun didukung oleh hasil observasi yang dapat dilihat pada Tabel 11 .

Tabel 11. Hasil Evaluasi Dimensi Fasilitas Pendukung

\begin{tabular}{|c|l|l|l|}
\hline No. & \multicolumn{1}{|c|}{ Indikator } & \multicolumn{1}{|c|}{ Kriteria } & \multicolumn{1}{c|}{ Hasil Observasi } \\
\hline 1. & Area Parkir & $\begin{array}{l}\text { Ketersediaan parkiran } \\
\text { kendaraan roda dua. }\end{array}$ & Tersedia. \\
\cline { 3 - 4 } & & $\begin{array}{l}\text { Ketersediaan parkiran } \\
\text { kendaraan roda empat. }\end{array}$ & Tersedia. \\
\cline { 3 - 4 } & $\begin{array}{l}\text { Area parkir menggunakan } \\
\text { perkerasan di area parkir harus } \\
\text { dilakukan dengan konstruksi } \\
\text { yang tidak mengganggu } \\
\text { penyerapan air dalam tanah. }\end{array}$ & $\begin{array}{l}\text { Area parkir masih terdiri } \\
\text { dari bebatuan dan tanah } \\
\text { merah. }\end{array}$ \\
\hline 2. & Akses untuk Disabilitas & $\begin{array}{l}\text { Ketersediaan akses untuk } \\
\text { disabilitas. }\end{array}$ & Tidak tersedia. \\
\hline 3. & Barbeku/ Fasilitas & Tersedia fasilitas barbeque/ & Tidak tersedia. \\
\hline
\end{tabular}




\begin{tabular}{|c|c|c|c|}
\hline No. & Indikator & Kriteria & Hasil Observasi \\
\hline & Memanggang & fasilitas memanggang. & \\
\hline \multirow[t]{2}{*}{4.} & \multirow[t]{2}{*}{ Fasilitas Toilet } & Fasilitas toilet bersih. & Tidak bersih. \\
\hline & & $\begin{array}{l}\text { Tersedia tanda yang jelas, air } \\
\text { bersih yang cukup, tempat cuci } \\
\text { tangan dan alat pengering, } \\
\text { kloset jongkok dan/atau kloset } \\
\text { duduk, tempat sampah } \\
\text { tertutup, dan tempat buang air } \\
\text { kecil (urinoir) pada fasilitas } \\
\text { toilet. }\end{array}$ & $\begin{array}{l}\text { Tanda yang jelas, air bersih, } \\
\text { dan kloset jongkok atau } \\
\text { kloset duduk telah tersedia } \\
\text { pada tiap toilet yang ada, } \\
\text { dan ketersediaan air yang } \\
\text { telah mencukupi. Namun, } \\
\text { tempat sampah yang } \\
\text { tertutup hanya tersedia pada } \\
9 \text { dari } 20 \text { toilet dan tempat } \\
\text { cuci tangan dan alat } \\
\text { pengering belum tersedia. }\end{array}$ \\
\hline 5. & Fasilitas Air Minum & $\begin{array}{l}\text { Ketersediaan fasilitas air } \\
\text { minum. }\end{array}$ & Tidak tersedia. \\
\hline \multirow[t]{3}{*}{6.} & \multirow[t]{3}{*}{$\begin{array}{l}\text { Fasilitas Kebersihan dan } \\
\text { Keamanan }\end{array}$} & $\begin{array}{l}\text { Ketersediaan fasilitas } \\
\text { kebersihan. }\end{array}$ & Tersedia. \\
\hline & & $\begin{array}{l}\text { Ketersediaan alat pemadam } \\
\text { api ringan (APAR). }\end{array}$ & Tersedia. \\
\hline & & Ketersediaan menara pandang. & Tidak tersedia. \\
\hline 7. & Jalur & $\begin{array}{l}\text { Jalur yang ada dapat dilewati } \\
\text { dengan mudah oleh pejalan } \\
\text { kaki. }\end{array}$ & $\begin{array}{l}\text { Jalur yang ada untuk dilalui } \\
\text { oleh pejalan kaki tidak } \\
\text { dapat dilalui dengan mudah. }\end{array}$ \\
\hline \multirow[t]{2}{*}{8.} & \multirow[t]{2}{*}{ Kursi / Bangku } & $\begin{array}{l}\text { Jumlah kursi yang tersedia } \\
\text { telah mencukupi kebutuhan } \\
\text { wisatawan. }\end{array}$ & Tersedia. \\
\hline & & $\begin{array}{l}\text { Seluruh kursi yang terdapat } \\
\text { dapat digunakan }\end{array}$ & $\begin{array}{l}\text { Terdapat } 1 \text { kursi yang tidak } \\
\text { dapat digunakan. }\end{array}$ \\
\hline 9. & Meja Piknik & $\begin{array}{l}\text { Meja piknik yang tersedia } \\
\text { telah mencukupi kebutuhan } \\
\text { wisatawan. }\end{array}$ & Tidak tersedia. \\
\hline \multirow[t]{3}{*}{10.} & \multirow[t]{3}{*}{ Outlet Makanan } & $\begin{array}{l}\text { Outlet makanan yang tersedia } \\
\text { tidak berdebu. }\end{array}$ & $\begin{array}{l}\text { Tidak ada debu pada outlet } \\
\text { makanan. }\end{array}$ \\
\hline & & $\begin{array}{l}\text { Tidak terdapat sampah } \\
\text { berserakan pada outlet } \\
\text { makanan yang tersedia }\end{array}$ & $\begin{array}{l}\text { Terdapat sampah } \\
\text { berserakan pada outlet } \\
\text { makanan. }\end{array}$ \\
\hline & & $\begin{array}{l}\text { Outlet makanan yang tersedia } \\
\text { tertata dengan rapi. }\end{array}$ & Tidak tertata dengan rapi. \\
\hline \multirow[t]{5}{*}{11.} & \multirow[t]{5}{*}{ Petunjuk } & Ketersediaan papan nama. & Tidak tersedia. \\
\hline & & Ketersediaan papan informasi. & Tidak tersedia. \\
\hline & & $\begin{array}{l}\text { Ketersediaan papan petunjuk } \\
\text { arah. }\end{array}$ & Tersedia. \\
\hline & & $\begin{array}{l}\text { Ketersediaan papan bina cinta } \\
\text { alam. }\end{array}$ & Tidak tersedia. \\
\hline & & $\begin{array}{l}\text { Ketersediaan papan } \\
\text { larangan/peringatan. }\end{array}$ & Tersedia. \\
\hline
\end{tabular}




\begin{tabular}{|c|c|c|c|}
\hline No. & Indikator & Kriteria & Hasil Observasi \\
\hline & & $\begin{array}{l}\text { Ketersediaan papan rambu lalu } \\
\text { lintas. }\end{array}$ & Tidak tersedia. \\
\hline 12. & Pertolongan Pertama & $\begin{array}{l}\text { Ketersediaan } \\
\text { pertama pada } \\
(\mathrm{P} 3 \mathrm{~K}) .\end{array}$ & $\begin{array}{l}\text { Tersedia, namun belum } \\
\text { memenuhi standar. }\end{array}$ \\
\hline 13. & Pintu Gerbang & Ketersediaan pintu gerbang. & Tidak tersedia. \\
\hline 14. & Pusat Informasi & $\begin{array}{l}\text { Pusat informasi yang tersedia } \\
\text { telah mencukupi kebutuhan } \\
\text { wisatawan. }\end{array}$ & Tersedia. \\
\hline \multirow[t]{2}{*}{15.} & \multirow[t]{2}{*}{ Tempat Bernaung/Berteduh } & Ketersediaan gazebo. & Tersedia. \\
\hline & & $\begin{array}{l}\text { Gazebo yang ada tidak } \\
\text { berlubang atau bocor. }\end{array}$ & $\begin{array}{l}\text { Terdapat lubang pada } \\
\text { gazebo. }\end{array}$ \\
\hline \multirow[t]{6}{*}{16.} & \multirow[t]{6}{*}{ Tempat Ibadah } & $\begin{array}{l}\text { Ketersediaan mushola atau } \\
\text { masjid. }\end{array}$ & Tersedia. \\
\hline & & $\begin{array}{l}\text { Karpet pada mushola atau } \\
\text { masjid tidak berbau. }\end{array}$ & $\begin{array}{l}\text { Karpet mushola tidak } \\
\text { berbau. }\end{array}$ \\
\hline & & $\begin{array}{l}\text { Lantai mushola atau masjid } \\
\text { tidak berdebu. }\end{array}$ & Lantai mushola berdebu. \\
\hline & & $\begin{array}{l}\text { Atap mushola atau masjid } \\
\text { tidak berlubang atau bocor. }\end{array}$ & $\begin{array}{l}\text { Atap mushola tidak } \\
\text { berlubang atau bocor. }\end{array}$ \\
\hline & & $\begin{array}{l}\text { Lantai mushola atau masjid } \\
\text { tidak berlubang. }\end{array}$ & Lantai mushola berlubang \\
\hline & & $\begin{array}{l}\text { Tempat wudhu mushola atau } \\
\text { masjid baik. }\end{array}$ & Keran wudhu rusak \\
\hline \multirow[t]{3}{*}{17.} & \multirow[t]{3}{*}{ Tempat sampah } & $\begin{array}{l}\text { Ketersediaan Tempat } \\
\text { Penampungan Sementara } \\
\text { (TPS). }\end{array}$ & Tidak tersedia. \\
\hline & & $\begin{array}{l}\text { Jumlah tempat sampah telah } \\
\text { mencukupi. }\end{array}$ & Tidak mencukupi \\
\hline & & $\begin{array}{l}\text { Terdapat sampah berserakan di } \\
\text { sekitar tempat sampah. }\end{array}$ & $\begin{array}{l}\text { Terdapat sampah } \\
\text { berserakan di sekitar tempat } \\
\text { sampah. }\end{array}$ \\
\hline 18. & Toko Suvenir & Ketersediaan toko suvenir. & Tidak tersedia \\
\hline
\end{tabular}

Sumber: Analisis Penyusun, 2019

Jika hasil pada Tabel 10 dipersentasekan, berdasarkan kriteria yang ada dapat diketahui bahwa terdapat $71 \%$ keadaan fasilitas yang tidak memenuhi kriteria sedangkan 29\% keadaan fasilitas telah memenuhi kriteria. Berdasarkan hasil Tabel 9 dan 10 maka dapat disimpulkan bahwa kualitas dimensi fasilitas dinilai kurang baik.

\section{KESIMPULAN DAN SARAN}

\subsection{Kesimpulan}

Berdasarkan hasil evaluasi aset fasilitas Wanawisata Punceling di Kabupaten Bandung, dapat disimpulkan bahwa: 
1. Kualitas aset fasilitas Wanawisata Punceling berdasarkan dimensi akomodasi, akses, daya tarik, dan fasilitas pendukung menunjukan hasil sebagai berikut:

a. Kualitas berdasarkan dimensi akomodasi menunjukan kualitas yang cukup baik. Hal ini ditandai dengan area perkemahan telah mencukupi kebutuhan akomodasi wisatawan dan area perkemahan cukup tertata dengan baik. Namun, penginapan pada Wanawisata Punceling belum tersedia.

b. Kualitas berdasarkan dimensi akses menunjukkan kualitas kurang baik meskipun masih dapat dilalui kendaraan bermotor dan pelayanan angkutan umum tersedia.

c. Kualitas berdasarkan dimensi daya tarik menunjukkan kualitas yang kurang baik. Hal ini ditandai dengan terdapat dinding kecoklatan pada kolam pemandian air panas dan kamar rendam serta belum tersedianya fasilitas outbound, kabel luncur (flying fox), jembatan antar tajuk pohon (canopy trail), balon udara, dan paralayang untuk menunjang fasilitas petualangan.

d. Kualitas berdasarkan dimensi fasilitas pendukung menunjukkan kualitas yang kurang baik. Hal ini ditandai dengan 71\% keadaan fasilitas yang tidak memenuhi kriteria sedangkan 29\% keadaan fasilitas telah memenuhi kriteria dengan kondisi eksisting meliputi:

1) Belum tersedianya fasilitas akses untuk disabilitas, fasilitas memanggang, fasilitas air minum, menara pandang, meja piknik, papan nama, papan informasi, papan bina cinta alam, pintu gerbang, tempat penampungan sementara (TPS), dan toko suvenir.

2) Tidak lengkapnya fasilitas toilet karena tidak tersedianya tempat cuci tangan, urinoir, dan tempat sampah yang ada di seluruh toilet di Wanawisata Punceling.

3) Fasilitas pertolongan pertama pada kecelakaan karena belum memenuhi standar.

4) Jalur yang ada untuk dilalui oleh pejalan kaki tidak dapat dilalui dengan mudah.

5) Tempat sampah yang tersedia belum mencukupi kebutuhan wisatawan.

6) Fasilitas ibadah yang ada dalam kondisi karpet yang berbau, lantai yang berdebu, lantai yang berlubang, dan keran wudhu yang rusak.

7) Outlet makanan yang tersedia tidak berdebu. Namun, outlet makanan tidak tertata dengan rapi serta terdapat sampah yang berserakan.

8) Terdapat lubang pada lantai gazebo. 


\subsection{Saran}

Saran yang diajukan berdasarkan kesimpulan sebagai berikut:

1. Saran yang ditujukan dari permasalahan berdasarkan dimensi akomodasi, akses, daya tarik, dan fasilitas pendukung adalah sebagai berikut:

a. Sebaiknya, penataan area perkemahan diatur dengan menentukan penempatan tenda pengunjung. Hal ini ditujukan agar pengunjung mendirikan tenda berdasarkan tempat yang telah tersedia sehingga lebih teratur. Hal tersebut berpengaruh pada estetika tempat wisata

b. Pihak pengelola perlu melapisi jalan dengan pengerasan batu dan lapisan permukaan aspal sehingga jalan yang dilalui wisatawan tidak licin sehingga lebih aman untuk dilewati.

c. Pengelola membuat perencanaan pemeliharaan secara periodik agar kondisi fasilitas rekreasi yang ada dapat termonitoring secara berkala.

d. Pengelola sebaiknya memerhatikan kenyamanan pengunjung dengan menyediakan dan melengkapi fasilitas pendukung sesuai standar yang berlaku. Kemudian, pengelola perlu melakukan perawatan dan monitoring terkait kondisi fasilitas pendukung yang telah tersedia di Wanawisata Punceling untuk menjaga kenyamanan pengunjung saat menggunakan fasilitas tersebut.

\section{DAFTAR PUSTAKA}

Aminuddin, I., Krishnadianty, D., Syukur, A. G., \& Dian, I. A. (2016). Panduan Pengembangan Akomodasi Wisata Ramah Lingkungan. Jakarta Selatan: WWFIndonesia.

Alaeddinoglu, F., \& Can, A. S. (2011). Identification and Classification of Nature-Based Tourism Resources: Western Lake Van basin, Turkey. Procedia Social and Behavioral Sciences, 19, 198-207.

AlKahtani, S., Xia, J., Veenendaaland, B., Caulfield, C., \& Hughes, M. (2015). Building a Conceptual Framework for Determining Individual Differences of Accessibility to Tourist Attractions. Tourism Management Perspectives, 16, 28-42.

Calidoni, F., \& Lundberg. (2006). Evaluation: Definitions, Methods and Models. Östersund: Swedish Institute For Growth Policy Studies. 
Ginting, N., \& Sasmita, A. (2018). Developing Tourism Facilities Based on Geotourism in Silalahi Village, Geopark Toba Caldera. IOP Conf. Series: Earth and Environmental Science, 126.

Hair, J. F., Andreson, R. E., Tatham, R. L., \& Black, W. C. (1998). Multivariate Data Analysis. New Jersey: Prentice Hall.

Kerlinger, F. N. (1986). Foundations of Behavioral Research. New York: Holt, Rinehart and Winston.

Moha, S., \& Loindong, S. (2016). Analisis Kualitas Pelayanan dan Fasilitas Terhadap Kepuasan Konsumen pada Hotel Yuta di Kota Manado. EMBA, 4, 575-584.

Panasiuk, A. (2007). Tourism Infrastructsure as a Determinant of Regional Development. Ekonomika ir Vadyba: Aktualijos ir Perspektyvos, 1, 212-215.

Peraturan Menteri Kehutanan Republik Indonesia Nomor P.22/Menhut-11/2012 tentang Pedoman Kegiatan Usaha Pemanfaatan Jasa Lingkungan Wisata Alam Pada Hutan Lindung, (2012).

Peraturan Menteri Pariwisata dan Ekonomi Kreatif Republik Indonesia Nomor 17 Tahun 2014 tentang Standar Usaha Kawasan Pariwisata, (2014).

Priskin, J. (2001). Assessment of Natural Resources for Nature-Based tourism: The Case of The Central Coast Region of Western Australia. Tourism Management, 22, 637-648.

Rahman, B. (2019, November). The Direction Concept of Leading Tourism Development of Amay Jayapura Beach Based on the Community Aspirations Results. In Journal of Physics: Conference Series (Vol. 1351, No. 1, p. 012092). IOP Publishing.

Roday, S., Biwal, A., Vandana, J., \& Joshi, V. (2009). Tourism Operations and Management: Oxford University Press.

Sekaran, U. (2006). Research Methods for Business. Jakarta: Salemba Empat.

Suhartanto, D. (2014). Metode Riset Pemasaran. Bandung: Alfabeta.

Sugiyono. (2017). Metode Penelitian Administrasi. Bandung: Alfabeta.

Utama, I. G. B. R. (2017). Pemasaran Pariwisata. Yogyakarta: Andi-Yogyakarta.

Warmbrod, J. R. (2014). Reporting and Interpreting Scores Derived from Likert-type Scales. Agricultural Education, 55, 30-47.

Wiyono, G. (2011). Merancang Penelitian Bisnis dengan Alat Analisis SPSS 17.0 \& SmartPLS 2.0. Yogyakarta: UPP STIM YKPN. 